\title{
Variability in ostracod communities (Crustacea, Ostracoda) in connected and isolated tropical floodplain lakes
}

\author{
Eliezer de Oliveira da Conceição ${ }^{1}$, Janet Higuti $^{2}$ and Koen Martens ${ }^{3,4, *}$ \\ ${ }^{1}$ Programa de Pós-Graduação em Ecologia de Ambientes Aquáticos Continentais, Universidade Estadual de Maringá, Av. Colombo, \\ 5790, CEP 87020-900 Maringá, PR, Brazil \\ ${ }^{2}$ Universidade Estadual de Maringá, Núcleo de Pesquisas em Limnologia, Ictiologia e Aquicultura, Programa de Pós-Graduação em \\ Ecologia de Ambientes Aquáticos Continentais, Av. Colombo, 5790, CEP 87020-900 Maringá, PR, Brazil \\ ${ }^{3}$ Royal Belgian Institute of Natural Sciences, Freshwater Biology, Vautierstraat 29, 1000 Brussels, Belgium \\ ${ }^{4}$ University of Ghent, Department of Biology, K.L. Ledeganckstraat 35, 9000 Ghent, Belgium
}

Received: 11 December 2016; Accepted: 18 July 2017

\begin{abstract}
Floodplains mostly consist of primary and secondary riverbeds, connecting channels and lakes that are either isolated from rivers and channels for most of the year, or lakes that are connected to rivers and channels for most (or all) of the year. We hypothesize that the differences in invertebrate communities, as calculated by beta-diversities, will be higher in isolated than in connected lakes. We use ostracod communities in the pleuston of the floating macrophyte Eichhornia crassipes in the Upper Paraná River floodplain to test this hypothesis. We have observed significant differences in species composition between the two types of lakes. However, although beta diversity values are indeed slightly higher in isolated than in connected lakes, these differences are not significant. This lack of clear effect of isolation on beta diversity could be owing to the fact that the period of isolation since the last homogenizing flood pulse had not been long enough, or because differences in degree of isolation become altogether insignificant in periods of low water flow.
\end{abstract}

Keywords: microcrustaceans / beta diversity / connectivity / Eichhornia crassipes / Paraná River

\section{Introduction}

Beta diversity can be defined as the difference in diversity among a set of communities (Melo et al., 2011). Understanding the mechanisms of beta diversity has been a central theme in community ecology (Anderson et al., 2011). This concept allows to describe the distribution of diversity through space and time (Jurasinski et al., 2009) and of environmental patterns of variation during turnover (Anderson et al., 2006). Understanding of both types of processes is important to improve ecosystem management (Legendre et al., 2005). Thus, the concept of beta diversity has been widely used during recent decades in studies of biological communities (Melo et al., 2011).

Different processes can cause changes in beta diversity. For instance, biological invasions can homogenize adjacent communities, as invasive species can be more competitive and might drive native species into extinction, thus drastically reducing beta diversity among communities (Clavero and García-Berthou, 2006; McCarthy et al., 2006). The replacement of specialist species by more generalist species reduces both taxonomic and functional diversity (Olden et al., 2004).

\footnotetext{
*Corresponding author: darwinula@gmail.com
}

Another factor that may influence beta diversity is environmental heterogeneity, and this is especially relevant in floodplains, which are characterized by seasonal changes of the hydrological regime, the so-called "flood pulses" (Junk et al., 1989). During the flood period, when water levels are high, connections between rivers and channels on the one hand, and adjacent aquatic biotopes such as floodplain lakes on the other hand, allow the transfer of matter, energy and organisms between such habitats, a phenomenon described as homogenization (Tockner et al., 2000; Thomaz et al., 2007). Therefore, such flood pulses may reduce environmental heterogeneity (Ward and Tockner, 2001) and may thus reduce the beta diversity within the floodplain (Bozelli et al., 2015). The connections between the habitats change according to the hydro-geomorphologic attributes of the main riverbed and can occur in small as well as in large rivers, of which the flood pulses can be for short or long flood periods, can be predictable or unpredictable, and can have large or small amplitudes (Junk et al., 1989).

The degree of connectivity between the floodplain lakes and their main river is a factor that influences both biotic and abiotic variables. For example, high concentrations of chlorophyll $a$ were recorded in isolated lakes, while concentrations of this variable were more reduced in connected 
lakes (Ahearn et al., 2006). The same pattern may occur for conductivity, concentrations of nitrate and of other nutrients (Thomaz et al., 2004). This fluctuation of environmental variables throughout the hydrological cycle changes the dynamics and structure of communities and can potentially raise the beta diversity among different habitats.

Ostracoda (Crustacea) are among the most common groups of organisms living on aquatic macrophytes (Poi de Neiff and Carignan, 1997; Higuti et al., 2010; Ohtaka et al., 2011). South America has several native floating aquatic plants. Their root systems harbor a rich community of vertebrates and invertebrates, including ostracods, called pleuston (Por and Rocha, 1998; Rocha and Por, 1998). Here, we assess the beta diversity of ostracods, associated with floating macrophytes, in connected and isolated lakes of three river systems of the upper Paraná River floodplain during the dry season. The main hypothesis we test is that the lack of flood pulses during the dry season promotes a higher beta diversity among isolated than connected lakes, because of the constant exchange of material between the main channel and the connected lakes. To make the relevance of exchanged material especially clear, we concentrate on ostracod communities in the pleuston of the floating plant Eichhornia crassipes (Mart.) Solms.

\section{Materials and methods}

\subsection{Study site}

The upper Paraná River runs $619 \mathrm{~km}$ in Brazil from the confluence of Grande and Paranaíba Rivers to Itaipu reservoir (Agostinho et al., 2008). Its basin has an area larger than $802150 \mathrm{~km}^{2}$ in Brazilian territory, including the states of Paraná, Mato Grosso do Sul, São Paulo, Minas Gerais and Goiás (Souza-Filho and Stevaux, 2004). The ecological integrity of this river basin has been threatened by the presence of 25 man-made reservoirs that affect $70 \%$ of the river, in addition to deforestation of riparian vegetation and intensive agriculture (Agostinho et al., 2000).

The upper Paraná River floodplain is located between the Porto Primavera and the Itaipu reservoirs. It is $230 \mathrm{~km}$ long and more than $20 \mathrm{~km}$ wide at its widest point. This floodplain is an anastomosing complex of the primary (Paraná) and secondary rivers (Baía and Ivinhema), channels, connected and isolated lakes (Fig. 1). Because of the biological and socioeconomic importance of this river-floodplain system, three conservation units were created in the upper Paraná River floodplain: the "Área de Proteção Ambiental das Ilhas e Várzeas do Rio Paraná" (Environmental Protection Area), the "Parque Nacional de Ilha Grande" (National Park), and the "Parque Estadual do Ivinheima" (State Park) (Agostinho et al., 2008).

\subsection{Field sampling and laboratory analysis}

Ostracods were collected on September 29 and October 1, 2010, in 18 lakes associated with the Ivinhema, Baía and Paraná rivers of the upper Paraná River floodplain. In each river, here named "system", three connected lakes and three isolated lakes were investigated (Fig. 1).

Free floating macrophytes, the common water hyacinth E. crassipes, were hand collected and immediately placed in plastic buckets. The leaves were discarded while the root systems were washed in a bucket to remove the ostracods. The residual was filtered in a hand net (mesh size $c a .160 \mu \mathrm{m}$ ) and samples were preserved in $70 \%$ ethanol. The roots were ovendried and weighed using a semi-analytical balance (Gehaka BK 3000). For an appraisal of the collecting methods used here, see Campos et al. (2017).

In the laboratory, the samples were divided using a Folsom fractioner, and $1 / 4$ of samples was quantified. However, species richness was always estimated from the total sample.

The ostracods were sorted under a stereoscopic microscope. The organisms were identified to species level using a set of specialized literature (see Martens and Behen, 1994 and articles comprised therein; Rossetti and Martens, 1998; Higuti and Martens 2012a, b, 2014; Higuti et al., 2013).

Physical and chemical water variables such as temperature $\left({ }^{\circ} \mathrm{C}\right)$ and dissolved oxygen $\left(\mathrm{mg} \mathrm{L}^{-1}\right)$ were measured with an oximeter YSI model 550A, while the values of $\mathrm{pH}$ and electrical conductivity $\left(\mu \mathrm{S} \mathrm{cm}^{-1}\right)$ were obtained using a YSI model 63. These variables were measured in situ before the collection of the ostracods.

Water level data were obtained from the LTER program (Long Term Ecological Research - http://www.peld.uem.br) developed by researchers of the Núcleo de Pesquisas em Limnologia, Ictiologia e Aquicultura (Nupelia) from the Universidade Estadual de Maringá.

\subsection{Data analysis}

Ostracod densities were calculated and estimated as individuals per gram of dry weight (ind $\mathrm{g}^{-1} \mathrm{DW}$ ) of the roots of E. crassipes.

A principal component analysis (PCA) was applied to order the abiotic data set (water temperature, $\mathrm{pH}$, electrical conductivity, dissolved oxygen). The abiotic matrix was log transformed, except for $\mathrm{pH}$, to minimize the effect of widely aberrant values. Axes were selected by the broken-stick method and the two selected axes (1 and 2) were used as response variables. Connection/isolation of lakes was the predictor variable in the analysis of variance (ANOVA), which was performed to test the ordination of abiotic factors. The assumptions of homogeneity and normality were fulfilled.

A principal coordinate analysis ( $\mathrm{PCoA}$ ) was performed to evaluate the (dis)similarity of species composition between the two classes of lakes (connected and isolated). The axes for analysis and ordination were retained, in accordance with the criteria of the broken-stick method. The sample scores of the axes 1 and 2 were submitted to a one-way ANOVA to test for the significance of the differences in species compositions between connected and isolated lakes. Moreover, the Pearson's correlation coefficient $(p<0.05)$ was applied to axes 1 and 2 of the PCoA to test for the association between abiotic factors (WT, pH, CE and DO) and the species composition.

To evaluate the variability of the beta diversity between the ostracod communities in connected and isolated lakes, we performed a dispersion homogeneity test (PERMDISP; Anderson, 2006). The test computes a centroid for each type of lake and determines the Bray-Curtis distance of each sampling point to the centroid. Thus, a higher average of the Bray-Curtis distance corresponds to a higher dissimilarity in species composition, which suggests an increase in the beta diversity. The significance level $(p<0.05)$ of the beta diversity 


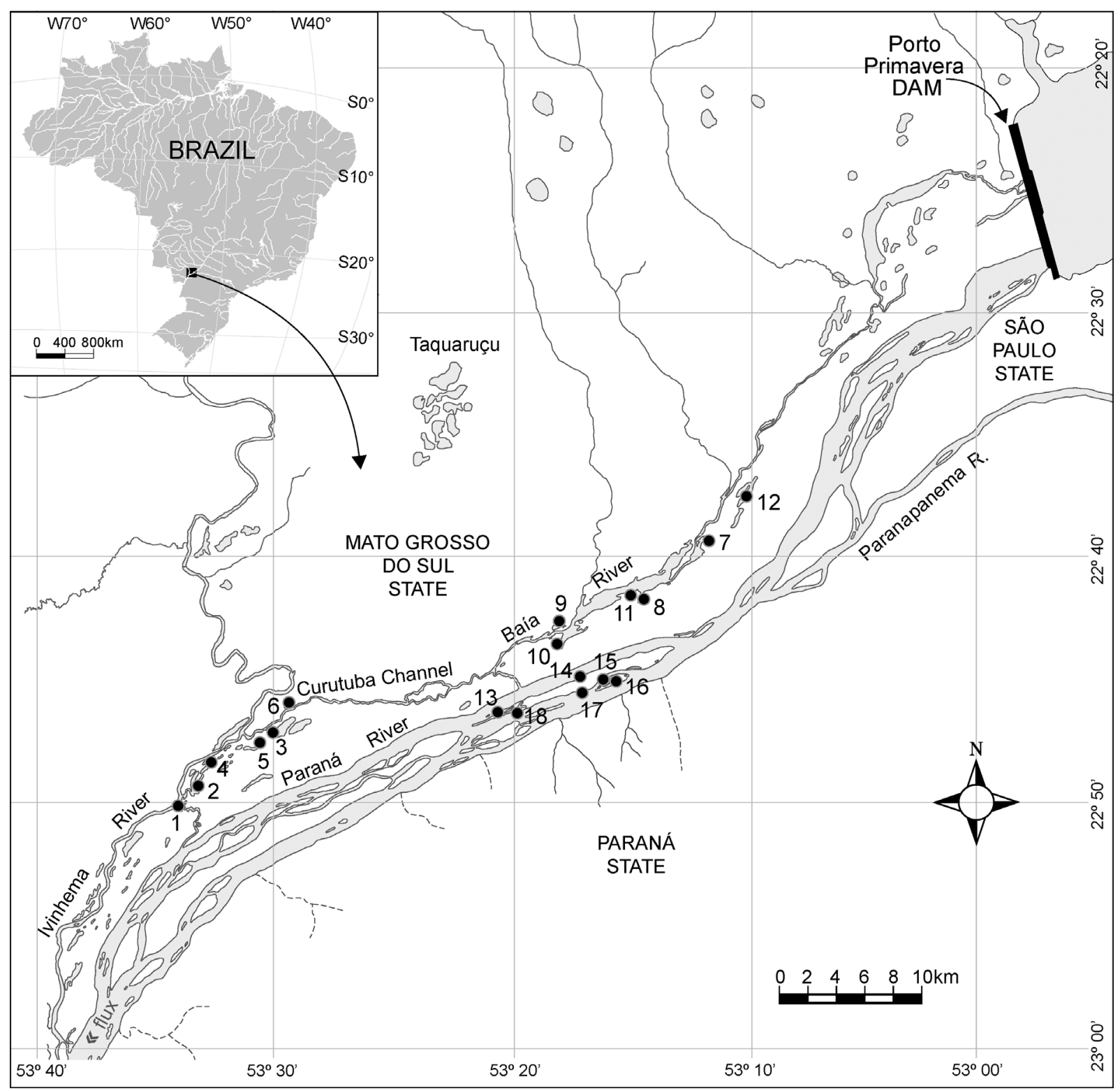

Fig. 1. Location of the lakes in the upper Paraná River floodplain. (1-6) Ivinhema River system, (7-12) Baía River system and (13-18) Paraná River system. See Table 1.

between the lakes was determined using a permutation test with 999 permutations.

Analyses were carried out in R 3.4 software (R Core Team, 2016) using the vegan (Oksanen et al., 2016) and permute (Simpson, 2016) packages.

\section{Results}

\subsection{Abiotic variables}

The abiotic variables of the lakes are listed in Table 1. In general, higher electrical conductivity and $\mathrm{pH}$ values were recorded in the Paraná River system, compared to those of the Baía and Ivinhema river systems. Lower values of dissolved oxygen were recorded in isolated lakes of the Paraná River system.
During the sampling days, the average water level of the Paraná River was $354 \pm 10 \mathrm{~cm}$. Daily water level readings during 2010 are shown in Figure 2.

The first two axes of the PCA explained $96.97 \%$ of the variance of the abiotic data. Axis 2 did not show a significant grouping of isolated and connected lakes. However, axis 1 showed a clustering of some isolated lakes (mainly of the Paraná River system - Fig. 3) and the ANOVA showed that this was significant $(p=0.02)$. The variables that presented a strong correlation $(\leq 0.5)$ in the second axis were dissolved oxygen $(r=0.49)$ and $\mathrm{pH}(r=0.39)$. The isolated lakes were grouped, particularly those of the Paraná River system, due the low concentration of dissolved oxygen $\left(0.1-0.2 \mathrm{mg} \mathrm{L}^{-1}\right)$, while the values of dissolved oxygen of connected lakes ranged from $5.8 \mathrm{mg} \mathrm{L}^{-1}$ to $7.7 \mathrm{mg} \mathrm{L}^{-1}$ (see Tab. 1). 
Table 1. Geographical location and environmental characteristics in the lakes of the upper Paraná River floodplain. Ivinhema (I), Baía (B), Paraná (P), water temperature (WT), hydrogen potential $(\mathrm{pH})$, electrical conductivity (EC) and dissolved oxygen (DO).

\begin{tabular}{|c|c|c|c|c|c|c|c|c|c|c|c|c|}
\hline Locality name & $\mathrm{S}^{\circ}$ & $\mathrm{S}^{\prime}$ & $\mathrm{S}^{\prime \prime}$ & $\mathrm{W}^{\circ}$ & $\mathrm{W}^{\prime}$ & $\mathrm{W}^{\prime \prime}$ & Lake & River system & WT $\left({ }^{\circ} \mathrm{C}\right)$ & $\mathrm{pH}$ & $\mathrm{EC}\left(\mu \mathrm{S} \mathrm{cm}^{-1}\right)$ & $\mathrm{DO}\left(\mathrm{mg} \mathrm{L}^{-1}\right)$ \\
\hline 2. Patos & 22 & 49 & 38.4 & 53 & 33 & 19.6 & Connected & I & 21 & 5.7 & 37 & 3.4 \\
\hline 4. Capivara & 22 & 48 & 15.2 & 53 & 32 & 14.4 & Isolated & I & 21.5 & 5.3 & 36.1 & 1.9 \\
\hline 5. Jacaré & 22 & 47 & 12.9 & 53 & 30 & 5.9 & Isolated & I & 21.4 & 5.9 & 29.9 & 4.0 \\
\hline 8. Porcos & 22 & 42 & 23.6 & 53 & 14 & 49.7 & Connected & $\mathrm{B}$ & 24.6 & 6.5 & 23.1 & 7.9 \\
\hline 9. Guaraná & 22 & 43 & 25.8 & 53 & 18 & 1.3 & Connected & $\mathrm{B}$ & 23.3 & 5.8 & 31.8 & 1.4 \\
\hline 10. Sete Figueira & 22 & 43 & 49.7 & 53 & 18 & 1.9 & Isolated & $\mathrm{B}$ & 22.4 & 5.7 & 79.5 & 0.2 \\
\hline 11. Bom Futuro & 22 & 42 & 7.9 & 53 & 14 & 51.4 & Isolated & B & 23.1 & 5.9 & 26 & 3.4 \\
\hline 12. V & 22 & 38 & 18.1 & 53 & 10 & 37.4 & Isolated & B & 24.7 & 6.3 & 24.4 & 7.3 \\
\hline 17. Sapateiro & 22 & 45 & 48.2 & 53 & 17 & 9.8 & Isolated & $\mathrm{P}$ & 21.4 & 6.1 & 49.3 & 0.2 \\
\hline 18. Cutia & 22 & 46 & 27.5 & 53 & 19 & 15.7 & Isolated & $\mathrm{P}$ & 20.9 & 5.8 & 124.4 & 0.1 \\
\hline
\end{tabular}

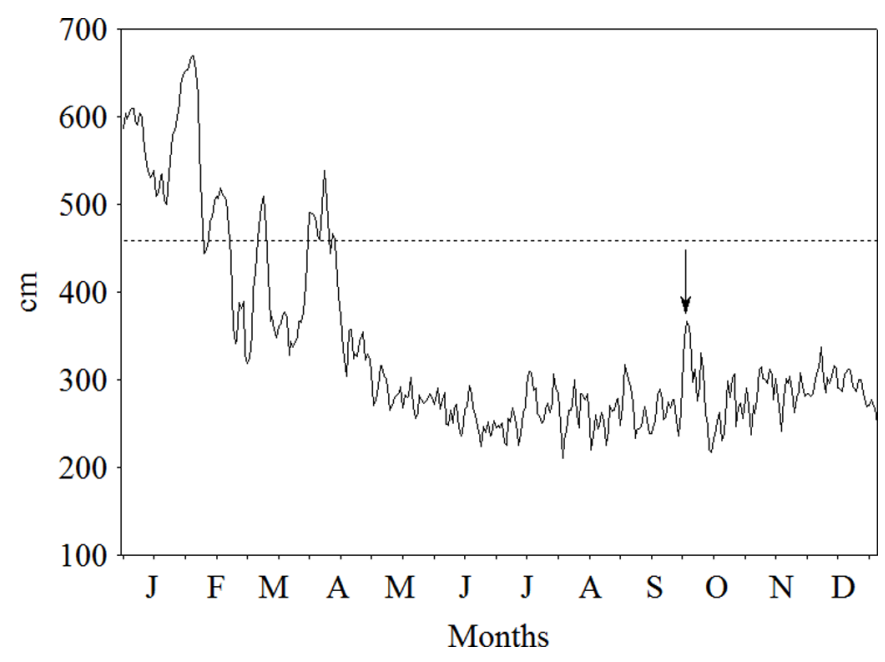

Fig. 2. Daily water level of the Paraná River in 2010 (January to December). Arrow: the period of collection, dashed line: water level at which adjacent lakes are flooded according to Souza-Filho (2009).

\subsection{Taxonomic richness}

We recorded 24 species of ostracods distributed in four families, the family Cyprididae had the highest richness (14 species), followed by Candonidae (6 species), Darwinulidae (3 species) and Limnocytheridae (1 species). Twenty-two species of ostracods were observed in samples from the connected lakes, and Diaphanocypris meridana (Furtos, 1936), Strandesia lansactohai Higuti and Martens in Higuti et al., 2013, Strandesia velhoi Higuti and Martens in Higuti et al., 2013, Strandesia n. sp., Cypridopsis cf. vidua sp. 2 and "Cypridopsis" n. gen. 2 n. sp. were collected exclusively from such lakes. Eighteen species of ostracods were recorded from isolated lakes and Strandesia

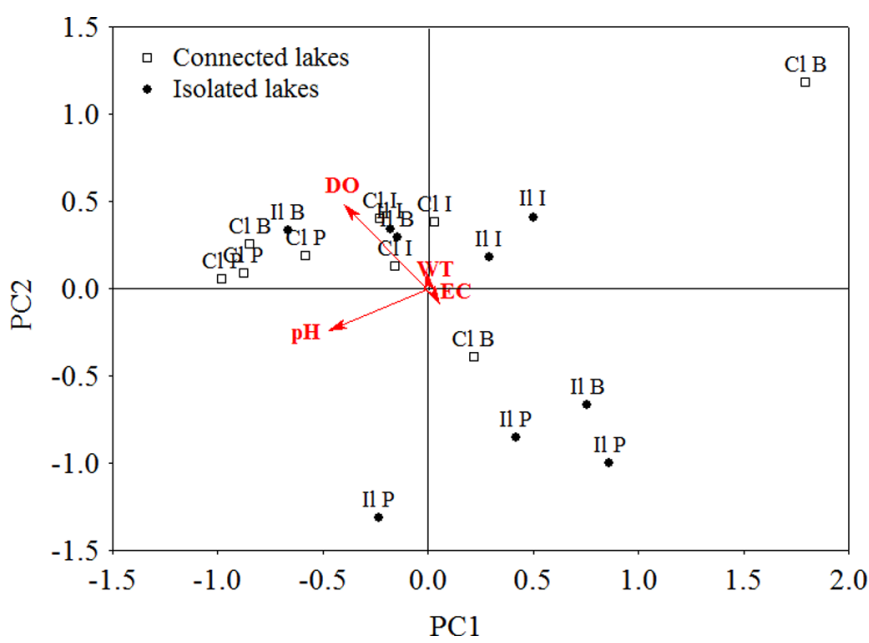

Fig. 3. Principal component analysis (PCA) of abiotic data. Water temperature (WT), hydrogen potential $(\mathrm{pH})$, electrical conductivity (EC), dissolved oxygen (DO), connected lakes (Cl), isolated lakes (I1), Ivinhema River system (I), Baía River system (B) and Paraná River system (P).

mutica (Sars, 1901) and Physocypria schubarti Farkas, 1958 occurred only in such environments. Cypricercus centrura (Klie, 1940), Cypretta costata G.W. Müller, 1898 and Candobrasilopsis elongata Higuti and Martens, 2014 were the most abundant species in connected lakes while Cytheridella ilosvayi Daday, 1905 was most abundant in the isolated lakes. In addition, S. mutica, S. lansactohai, S. velhoi and "Cypridopsis" n. gen. 2 n. sp. were recorded only in Paraná River system and lower richness was observed in the isolated lakes of this river system (Tab. 2). 
Table 2. Mean values and standard deviation of ostracod density (ind $\mathrm{g}^{-1} \mathrm{DW}$ ) in connected and isolated lakes of the upper Paraná River floodplain in Ivinhema, Baía and Paraná rivers systems.

\begin{tabular}{|c|c|c|c|c|c|}
\hline & \multicolumn{2}{|c|}{ Ivinhema } & \multicolumn{2}{|c|}{ Baía } & $-\frac{\text { Paraná }}{\text { Connected Isolated }}$ \\
\hline \multicolumn{6}{|l|}{ Family Cyprididae } \\
\hline Diaphanocypris meridana (Furtos, 1936) & $0.02 \pm 0.04$ & & & & $0.62 \pm 0.56$ \\
\hline Bradleystrandesia trispinosa (Pinto and Purper, 1965) & $0.08 \pm 0.15$ & $0.25 \pm 0.21$ & & $0.02 \pm 0.03$ & $0.97 \pm 1.13$ \\
\hline Strandesia mutica (Sars, 1901) & & & & & $0.04 \pm 0.07$ \\
\hline
\end{tabular}

Higuti et al. (2013)

Strandesia velhoi Higuti and Martens in Higuti et al. (2013)

Strandesia nupelia Higuti and Martens in Higuti et al. (2013)

Strandesia n. sp.

Cabelodopsis hispida (Sars, 1901)

Cypricercus centrura (Klie, 1940)

Chlamydotheca iheringi (Sars, 1901)

Cypretta costata G.W. Müller, 1898

C. cf. vidua sp. 2

"Cypridopsis" n. gen. 2 n. sp.

\begin{tabular}{|c|c|c|c|c|}
\hline & & & & $0.01 \pm 0.01$ \\
\hline & $0.01 \pm 0.02$ & $0.01 \pm 0.01$ & & $0.06 \pm 0.07$ \\
\hline & & $0.08 \pm 0.14$ & & \\
\hline $0.12 \pm 0.13$ & $0.42 \pm 0.52$ & & & $0.16 \pm 2.39$ \\
\hline $5.27 \pm 6.38$ & $0.18 \pm 1.49$ & $0.65 \pm 0.49$ & $0.36 \pm 0.31$ & $2.08 \pm 2.07$ \\
\hline $0.02 \pm 0.04$ & $0.04 \pm 0.05$ & $0.03 \pm 0.03$ & $0.04 \pm 0.06$ & \\
\hline $0.06 \pm 0.04$ & $2.50 \pm 4.00$ & $1.68 \pm 2.07$ & $1.51 \pm 1.68$ & $3.14 \pm 1.14$ \\
\hline $0.03 \pm 0.06$ & & & & \\
\hline & & & & $0.01 \pm 0.01$ \\
\hline & $0.03 \pm 0.05$ & $0.08 \pm 0.14$ & $0.14 \pm 0.24$ & $0.07 \pm 0.070 .02 \pm 0.03$ \\
\hline $0.17 \pm 0.29$ & & $0.78 \pm 0.46$ & $0.73 \pm 0.5$ & \\
\hline $1.32 \pm 1.16$ & $3.37 \pm 2.25$ & $5.98 \pm 3.13$ & $2.77 \pm 1.99$ & \\
\hline & $0.06 \pm 0.11$ & $0.18 \pm 0.18$ & $0.19 \pm 0.31$ & \\
\hline $0.19 \pm 0.22$ & & & $0.14 \pm 0.24$ & \\
\hline & & & $0.05 \pm 0.09$ & \\
\hline
\end{tabular}

\section{Family Candonidae}

Candobrasilopsis brasiliensis (Sars, 1901)

C. rochai Higuti and Martens, 2012

C. elongata Higuti and Martens, 2014

Pseudocandona cillisi Higuti and Martens, 2014

P. agostinhoi Higuti and Martens, 2014

Physocypria schubarti Farkas, 1958

$0.05 \pm 0.09$

\section{Family Limnocytheridae}

Cytheridella ilosvayi Daday, 1905

$11.78 \pm 10.60118 .89 \pm 155.2035 .54 \pm 22.4332 .23 \pm 26.462 .15 \pm 1.170 .26 \pm 0.26$

\section{Family Darwinulidae}

Alicenula serricaudata (Klie, 1935)

Vestalenula pagliolii (Pinto and Kotzian, 1961)

Penthesilenula brasiliensis (Pinto and Kotzian, 1961)

$\begin{array}{lllll}0.04 \pm 0.03 & 2.12 \pm 3.61 & 2.25 \pm 1.08 & 2.85 \pm 4.13 & 0.64 \pm 0.320 .03 \pm 0.05 \\ 0.63 \pm 0.56 & 1.42 \pm 2.09 & 0.19 \pm 0.17 & 0.25 \pm 0.17 & 1.30 \pm 0.710 .16 \pm 0.14 \\ 0.11 \pm 0.19 & 0.82 \pm 1.26 & 0.08 \pm 0.14 & 0.14 \pm 0.16 & 0.22 \pm 0.32\end{array}$

\subsection{Species composition and beta diversity}

The PCoA results ordered connected and isolated lakes, with the axis 2 showing significant differences in species composition (axis $2: F=7.39, p=0.02$ ) between the two types of lakes. The Pearson's correlation coefficient showed a significant negative relationship between species composition and dissolved oxygen $(R=-0.73 ; p=0.01)$ on axis 2 .

The difference in beta diversity (species composition variability) between connected and isolated lakes was not significant (PERMDISP, $F=1.11, p=0.31$ ), even though the average distance to the centroid was higher in isolated lakes $(0.5352)$ as compared to that in the connected lakes $(0.4506)$ (Fig. 4).

\section{Discussion}

The flood pulse in the Paraná River floodplain is considered to be irregular when compared to other river floodplains of South America, because it is artificially controlled by the reservoirs located upstream of this floodplain. The period of low water level can change from few days to several months over the years, and the same asymmetry is possible for the period of high water level (Thomaz et al., 2007). According to Souza-Filho (2009), the overflow of channels and adjacent lakes in the upper Paraná River floodplain occurs when the river water levels are higher than $4.6 \mathrm{~m}$. When this stage of connectivity is reached, phytoplankton, zooplankton, fish and macrophyte communities become 


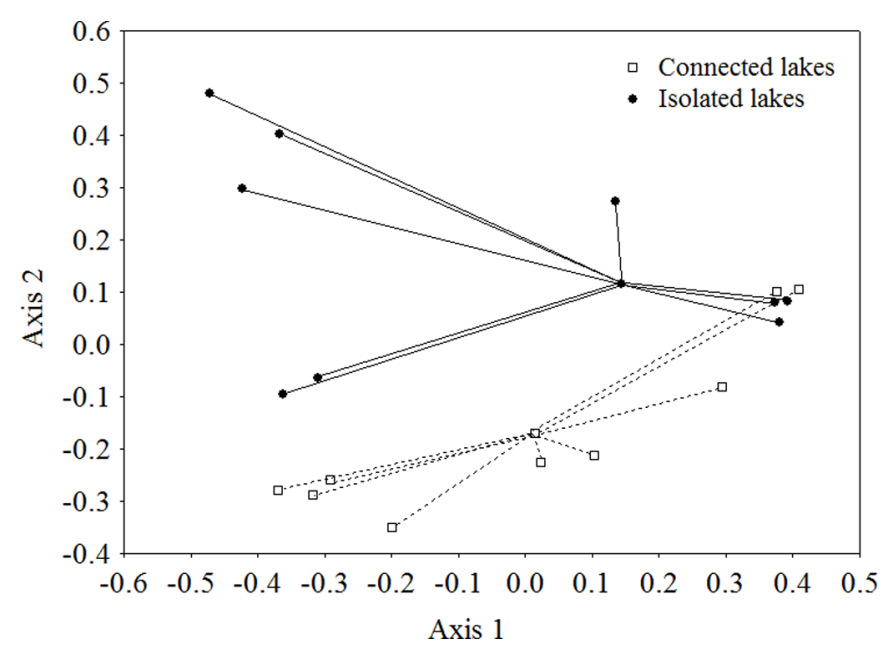

Fig. 4. Multivariate permutation analysis diagram showing the variation in beta diversity of ostracods species between connected and isolated lakes in the upper Paraná River floodplain.

more homogeneous between habitats (Nabout et al., 2007; Thomaz et al., 2007). However, the opposite might be true during low water level, when the habitats are fragmented and the species compositions can become more heterogeneous.

Dissolved oxygen was the only factor significantly related to species composition in the isolated lakes, especially in the Paraná River system. A particular group of five species, four non-swimmers and one swimmer (S. mutica), were recorded in isolated lakes of the Paraná River system compared with 14 species in connected lakes in this system (see Tab. 2). The fact that these lakes are often shallow during dry periods causes root systems of floating plants to be in direct contact with sediments. Non-swimming species can then more easily colonize the root systems of floating plants like E. crassipes, and this may be facilitated by lower oxygen levels near sediments (but see Liberto et al., 2012). Sampaio and López (2000) found that the diversity and abundance of cladocerans and rotifers increased due to the influence of high hydrological levels in improving the oxygen content in floodplain lakes. In addition, some species, e.g., the North American Candona caudata (Candonidae) can survive at low oxygen concentrations because of its rapid life cycle and the resulting production of eggs before the anoxic events in the habitat (Delorme, 1978).

We hypothesized that connected lakes would have a lower beta diversity than isolated lakes, because connected lakes will theoretically allow for faster homogenization of communities (Lopes et al., 2014). In connected lakes, dispersal is facilitated by the connectivity with the river and consequently a decrease in beta diversity is expected (Gonzalez, 2009). Indeed, although the dispersal of ostracods can occur by birds (Brochet et al., 2010), by wind carrying the drought resistant ostracod eggs (Vanschoenwinkel et al., 2008), or by human activity (Waterkeyn et al., 2010), the most common route of dispersion of invertebrates in floodplains is through the hydrological connections, mainly passively through the movements of macrophytes, vertebrates and other invertebrates.

Despite these theoretical assumptions, the observed differences in beta diversity between connected and isolated lakes were not significant in the present study, even though the beta diversities in isolated lakes were slightly higher. The present results agree with those of Higuti et al. (2009) which also showed slightly higher beta diversity values for isolated lakes as compared to those of connected lakes, but not significantly so.

There may be two reasons for this lack of significant differences in beta diversity (besides low number of samples). Firstly, at the time of our collections, isolated lakes had been disconnected from the main channels for about five and a half months (see Fig. 2). This period might have been too short to effectively result in significant differences in beta diversity between the two types of lakes. Secondly, low variation in beta diversity was also found by Bonecker et al. (2005) for rotifer communities. According to these authors, this was owing to a lack of flows during the dry season, both in isolated and connected lakes. It could thus be that the differences between isolated and connected lakes are insignificant during low water levels, as even connected lakes might experience little or no exchange of biological materials because of the lack of significant flows.

In conclusion, whereas we observed significant differences in species composition between the two types of lakes, we cannot presently corroborate the hypothesis that isolated lakes have a significantly higher beta diversity than connected lakes. Most likely, the irregular and often unpredictable events of high flooding (the so-called flood pulses) have homogenizing effects that may only be countered by longer periods of isolation. Only if flood pulses would be apart by longer periods of time, for example several years, could significant results of isolation in non-connected lakes in floodplains become visible. Alternatively, absence of significant water flows during periods of low water levels might nullify potential hydrological differences between connected and isolated lakes altogether.

Acknowledgments. We thank to National Council for Scientific and Technological Development (CNPq, Long Term Ecological Research - LTER) and the Academic Excellency Program (Proex) for financial support, Nucleus of Research in Limnology, Ichthyology and Aquaculture (Nupelia) and PostGraduate Program in Ecology of Aquatic Environments Continental (PEA) of the State University of Maringá (UEM) for the logistic support. We would like to thank Dr Roger Paulo Mormul for statistical assistance and Jaime Luiz Lopes Pereira for production of the map. The first author would like to thank CNPq for granting his MSc scholarship. The State University of Maringá (UEM, Maringá) and the Royal Belgian Institute of natural Sciences (RBINS, Brussels) have a bilateral Memorandum of Understanding regarding collaborative Scientific Research.

\section{References}

Agostinho AA, Thomaz SM, Minte-Vera CV, Winemiller KO. 2000. Biodiversity in the high Paraná River floodplain. In: Gopal B, Junk WJ, Davis JA, eds. Wetlands biodiversity: assessment, function and conservation. Leiden: Backhuys Publishers, pp. 89-118.

Agostinho AA, Pelicice FM, Gomes LC. 2008. Dams and the fish fauna of the Neotropical region: impacts and management related to diversity and fisheries. Braz J Biol 68: 1119-1132. 
Ahearn D, Viers JH, Mount JF, Dahlgren RA. 2006. Priming the productivity pump: flood pulse driven trends in suspended algal biomass distribution across a restored floodplain. Freshw Biol 51: 1417-1433.

Anderson MJ, Ellingsen KE, McArdle BH. 2006. Multivariate dispersion as a measure of beta diversity. Ecol Lett 9: 683-693.

Anderson MJ, Crist TO, Chase JM, Vallend M, Inouye BD, Freestone AL, Sanders NJ, Cornell HV, Comita LS, Davies KF, Harrison SP, Kraft NJB, Stegen JC, Swenson NG. 2011. Navigating the multiple meanings of $\beta$ diversity: a roadmap for the practicing ecologist. Ecol Lett 14: 19-28.

Bonecker CC, Costa CL, Velho LFM, Lansac-Tôha FA. 2005. Diversity and abundance of the planktonic rotifers in different environments of the Upper Paraná River floodplain (Paraná State Mato Grosso do Sul State, Brazil). Hydrobiologia 546: 405-414.

Bozelli RL, Thomaz SM, Padial AA, Lopes PM, Bini LM. 2015. Floods decrease zooplankton beta diversity and environmental heterogeneity in an Amazonian floodplain system. Hydrobiologia 753: 233-241.

Brochet AL, Gauthier-Clerc M, Guillemain M, Fritz H, Waterkeyn A, Baltanás Á, Green AJ. 2010. Field evidence of dispersal of branchiopods, ostracods and bryozoans by teal (Anas crecca) in the Camargue (southern France). Hydrobiologia 637: 255-261.

Campos R, Conceicão EO, Pinto MBO, Bertoncin APS, Higuti J, Martens K. 2017. Evaluation of quantitative sampling methods in pleuston: an example from ostracod communities. Limnologica 63 : 36-41.

Clavero M, García-Berthou E. 2006. Homogenization dynamics and introduction routes of invasive freshwater fish in the Iberian Peninsula. Ecol Appl 16: 2313-2324.

Delorme LD. 1978. Distribution of freshwater ostracodes in Lake Erie. J Great Lakes Res 4: 216-220.

Gonzalez A. 2009. Metacommunities: spatial community ecology. In: Encyclopedia of Life Sciences (eLS). Chichester: John W. and Sons Ltd, pp. 1-8.

Higuti J, Lansac-Tôha FA, Velho LFM, Martens K. 2009. Biodiversity of non-marine ostracods (Crustacea, Ostracoda) in the alluvial valley of the upper Paraná River, Brazil. Braz J Biol 69: 661-668.

Higuti J, Declerck SAJ, Lansac-Tôha FA, Velho LFM, Martens K. 2010. Variation in ostracod (Crustacea, Ostracoda) communities in the alluvial valley of the upper Paraná River (Brazil) in relation to substrate. Hydrobiologia 644: 261-278.

Higuti J, Martens K. 2012a. On a new cypridopsine genus (Crustacea, Ostracoda, Cyprididae) from the Upper Paraná River Floodplain (Brazil). Zootaxa 3391: 22-38.

Higuti J, Martens K. 2012b. Description of new genus and species of Candonopsini (Crustacea, Ostracoda, Candoninae) from the alluvial valley of the Upper Paraná River (Brazil, South America). Eur J Taxon 33: 1-31.

Higuti J, Martens K. 2014. Five new species of Candoninae (Crustacea, Ostracoda) from the alluvial valley of the Upper Paraná River (Brazil, South America). Eur J Taxon 106: 1-36.

Higuti J, Schön I, Audenaert L, Martens K. 2013. On the Strandesia obtusata/elliptica lineage (Ostracoda, Cyprididae) in the alluvial valley of the upper Paraná River (Brazil), with the description of three new species. Crustaceana 86: 182-211.

Junk WJ, Bayley PB, Sparks RE. 1989. The flood pulse concept in river floodplain systems. Can J Fish Aquat Sci 106: 110-127.

Jurasinski G, Retzer V, Beierkuhnlein C. 2009. Inventory, differentiation, and proportional diversity: a consistent terminology for quantifying species diversity. Oecologia 159: 15-26.
Legendre P, Bocard D, Peres-Neto PR. 2005. Analyzing beta diversity: partitioning the spatial variation of community composition data. Ecol Monogr 75: 435-450.

Liberto R, Mesquita-Joanes F, César I. 2012. Dynamics of pleustonic ostracod populations in small ponds on the Island of Martín García (Río de la Plata, Argentina). Hydrobiologia 688: 47-61.

Lopes OM, Bini LM, Declerck SAJ, Farjalla VF, Vieira LCG, Bonecker CC, Lansac-Tôha FA, Esteves FA, Bozelli RL. 2014. Correlates of zooplankton beta diversity in tropical lake systems. PLOS ONE 9: 1-8.

Martens K, Behen F. 1994. A checklist of the non-marine ostracods (Crustacea, Ostracoda) from the inland waters of South America and adjacent islands. Trav Sci Mus Nat Hist Nat Luxemb 22: 1-81.

McCarthy JM, Hein CL, Olden JD, Vander Zanden MJ. 2006. Coupling long-term studies with meta-analysis to investigate impacts of non-native crayfish on zoobenthic communities. Freshw Biol 51: 224-235.

Melo AS, Schneck F, Hepp LU, Simões NR, Siqueira T, Bini LM. 2011. Focusing on variation: methods and applications of the concept of beta diversity in aquatic ecosystems. Acta Limnol Bras 3: 318-331.

Nabout JC, Nogueira IS, Oliveira LG, Morais RR. 2007. Phytoplankton diversity (alpha, beta, and gamma) from the Araguaia River tropical floodplain lakes (central Brazil). Hydrobiologia 557: 455-461.

Ohtaka A, Narita T, Kamiya T, Katakura H, Araki Y, Im S, Chhay R, Tsukawaki S. 2011. Composition of aquatic invertebrates associated with macrophytes in Lake Tonle Sap, Cambodia. Limnology 12: 137-144.

Oksanen J, Blanchet GF, Friendly M, Kindt R, Legendre P, McGlinn D, Minchin PR, O'Hara RB, Simpson GL, Solymos P, Stevens MHH, Szoecs E, Wagner H. 2016. vegan: Community Ecology Package. R package version 2.4-0. https://CRAN.R-project.org/ package $=$ vegan.

Olden JD, Poff NL, Douglas MR, Douglas ME, Faush KD. 2004. Ecological and evolutionary consequences of biotic homogenization. Trends Ecol Evol 19: 18-24.

Poi de Neiff A, Carignan R. 1997. Macroinvertebrates on Eichhornia crassipes roots in two lakes of the Parana River floodplain. Hydrobiologia 345: 185-196.

Por FD, Rocha EF. 1998. The Pleustal, a third limnic biochore and its neotropical centre. Verh Int Ver Limnol 26: 1876-1881.

R Core Team. 2016. R: a language and environment for statistical computing. Vienna, Austria: R Foundation for Statistical Computing. ISBN 3-900051-07-0, http://www.R-project.org/.

Rocha CEF, Por FD. 1998. Preliminary comparative data on the fauna of the pleuston in the southern Pantanal, Brazil, with emphasis on the microcrustaceans. Verh Int Ver Limnol 26: 2137-2140.

Rossetti G, Martens K. 1998. Taxonomic revision of the Recent and Holocene representatives of the Family Darwinulidae (Crustacea, Ostracoda), with a description of three new genera. Bull Inst $R \mathrm{Sci}$ Nat Belg Biol 68: 55-110.

Sampaio EV, López CM. 2000. Zooplankton community composition and some limnological aspects of an oxbow lake of the Paraopeba River, São Francisco River Basin, Minas Gerais, Brazil. Braz Arch Biol Technol 43: 285-293.

Simpson GL. 2016. Permute: functions for generating restricted permutations of data. R Package, version 0.9-0. https:/CRAN.Rproject.org $/$ package $=$ permute.

Souza-Filho EE. 2009. Evaluation of the Upper Paraná River discharge controlled by reservoirs. Braz J Biol 69: 707-719.

Souza-Filho EE, Stevaux JC. 2004. Geology and geomorphology of the Baía-Curutuba-Ivinhema River Complex. In: Thomaz SM, Agostinho AA, Hahn NS, eds. The Upper Paraná River and its 
floodplain: physical aspects, ecology and conservation. Leiden: Backhuys Publishers, pp. 1-29.

Thomaz SM, Pagioro TA, Bini LM, Roberto MC, Rocha RRA. 2004. Limnological characterization of the aquatic environments and the influence of hydrometric levels. In: Thomaz SM, Agostinho AA, Hahn NS, eds. The Upper Paraná River and its floodplain: physical aspects, ecology and conservation. Leiden: Backhuys Publishers, pp. 75-102.

Thomaz SM, Bini LM, Bozelli RL. 2007. Floods increase similarity among aquatic habitats in river-floodplain systems. Hydrobiologia 579: 1-13.
Tockner K, Malard F, Ward JV. 2000. An extension of the flood pulse concept. Hydrol Process 14: 2861-2883.

Vanschoenwinkel B, Gielen S, Seaman M, Brendock L. 2008. Any way the wind blows - frequent wind dispersal drives species sorting in ephemeral aquatic communities. Oikos 117: 125-134.

Waterkeyn A, Vanschoenwinkel B, Elsen S, Anton-Pardo M, Grillas P, Brendonck L. 2010. Unintentional dispersal of aquatic invertebrates via footwear and motor vehicles in a Mediterranean wetland area. Aquat Conserv 20: 580-587.

Ward JV, Tockner K. 2001. Biodiversity: towards a unifying theme for river ecology. Freshw Biol 46: 807-819.

Cite this article as: Conceição EO, Higuti J, Martens K. 2017. Variability in ostracod communities (Crustacea, Ostracoda) in connected and isolated tropical floodplain lakes. Ann. Limnol. - Int. J. Lim. 53: 325-332. 